\title{
Keanggotaan Notaris Dalam Organisasi Ikatan Notaris Indonesia: Mandatory Vs Voluntary
}

\author{
Ida Ayu Kade Rienda Cintya Dewi ${ }^{1}$
}

1Fakultas Hukum Magister Kenotariatan Universitas Udayana, E-mail: cintyarienda@gmail.com, WA: 085953934259

\begin{tabular}{l}
\hline Info Artikel \\
\hline Keywords : \\
Notary, Indonesian Notary \\
Bond, Voluntary, Mandatory, \\
Sanction. \\
\\
\\
Kata kunci: \\
Notaris, Ikatan Notaris \\
Indonesia, Voluntary, \\
Mandatory, Sanksi. \\
Corresponding Author: \\
Ida Ayu Kade Rienda Cintya \\
Dewi, E-mail: \\
cintyarienda@gmail.com
\end{tabular}

\begin{abstract}
There is a vague norm in the UUJN regarding the word "mandate" which is regulated by Article 16 paragraph (1) letter $a$ of the UUJN if it is associated with the obligation of membership of a Notary as a member of INI organization. Based on the obscurity of these norms, the formulation of the problem is formulated, namely: (1) How is the regulation of the obligations of Notary Membership in INI according to the UUJN? (2) What is the sanction if a Notary is not a member in INI?

The purpose of this writing is generally related to notary fields in legal studies relating to membership of notaries in INI. Based on these general objectives, the specific purpose is to find out and understand how to regulate the obligations for membership of Notaries in INI according to the UUJN; and to review and analyze how sanctions are if a Notary is not a member of INI. Normative legal research is used in this study which is carried out by a conceptual approach (Conceptual Approach) and the statutory approach (The Statute Approach). Primary, secondary and tertiary legal materials are used in this study as a source of legal material with legal material collection techniques using a single method namely literature study in normative legal research that is applied with the use of snow ball methods.

This study provides results in the form of: (1) Notaries must become members of INI organization, as contained in the UUJN that notaries are obliged to act trustworthy. The act of trust is interpreted as something entrusted to the unity of people, which in this case is INI. Arrangements regarding notary membership obligations in INI are contained in the UUJN, the Notary Code of Ethics and the Constitutional Court Decision; and (2) Notaries who do not participate in INI membership receive sanctions in the form of written warnings, temporary terminations, respectful terminations, or dishonorable dismissals.

\begin{tabular}{l} 
Abstrak \\
\hline Terdapat kekaburan norma dalam UUJN mengenai kata \\
"amanah" yang diatur oleh Pasal 16 ayat (1) huruf a UUJN \\
apabila dikaitkan dengan kewajiban keanggotaan Notaris sebagai \\
anggota organisasi INI. Berdasarkan kekaburan norma tersebut, \\
dirumuskan rumusan permasalahan, yakni: (1) Bagaimana \\
pengaturan kewajiban keanggotaan Notaris dalam INI menurut \\
UUJN? (2) Bagaimana sanksi apabila seorang Notaris tidak ikut \\
menjadi anggota dalam INI? \\
Tujuan penulisan ini berkaitan dengan bidang kenotariatan \\
dalam kajian hukum yang berkaitan dengan keanggotaan notaris
\end{tabular}
\end{abstract}


DOI :

10.24843/AC.2018.v03.i02.p04 dalam INI. Berdasarkan tujuan umum tersebut adapun tujuan khususnya adalah untuk mengetahui dan memahami bagaimana pengaturan kewajiban keanggotaan Notaris dalam INI menurut UUJN; dan untuk mengkaji dan menganalisis Bagaimana sanksi apabila seorang Notaris tidak ikut menjadi anggota dalam INI. Penelitian hukum normatif dipergunakan dalam penelitian ini yang dilakukan dengan pendekatan konseptual (Conceptual Approach) serta pendekatan perundang-undangan (The Statute Approach). Bahan hukum primer, sekunder dan tersier dipergunakan dalam penelitian ini sebagai sumber bahan hukum dengan teknik pengumpulan bahan hukum menggunakan metode tunggal yakni studi kepustakaan dalam penelitian hukum normatif yang diterapkan dengan penggunaan metode bola salju (snow ball).

Penelitian ini memberikan hasil: (1) Notaris wajib menjadi anggota dalam organisasi INI, sebagaimana yang terdapat dalam UUJN bahwa notaris wajib untuk bertindak amanah. Tindakan amanah ditafsirkan sebagai sesuatu yang dipercayakan kepada kesatuan orang, yang dalam hal ini adalah INI. Pengaturan mengenai kewajiban keangggotaan notaris dalam INI terdapat dalam UUJN, Kode Etik Notaris dan Putusan MK; dan (2) Notaris yang tidak ikut dalam keanggotaan INI mendapatkan sanksi berupa peringatan tertulis, pemberhentian sementara, pemberhentian dengan hormat, atau pemberhentian dengan tidak hormat.

\section{Pendahuluan}

Norma hukum adalah aturan yang dibentuk pihak yang berkepentingan sebagai pedoman dalam berperilaku di masyarakat. Norma hukum berfungsi untuk menguasakan, memerintah, menyimpang, membolehkan, hingga melarang suatu aturan yang perlu diikuti.

Pada umumnya, norma hukum memiliki sifat, yakni mewajibkan (mandatory) dan mengatur (voluntary). Norma hukum yang bersifat mewajibkan merupakan norma yang wajib ditaati bagaimanapun keadaan, waktu, maupun tempat kepada pihak yang ditujukan oleh norma tersebut, sedangkan norma mengatur merupakan norma yang dapat dilakukan namun dapat juga tidak dilakukan, berbeda halnya dengan sifat norma yang mewajibkan, sifat norma mengatur tidak memiliki sanksi karena norma tersebut dibuat kepada para pihak yang dituju oleh norma agar dapat dipergunakan atau tidak itu tergantung pada pihak tersebut. Peraturan perundang-undangan adalah norma hukum yang dibuat secara tertulis dan dibuat untuk ditujukan kepada pihak yang diatur oleh norma tersebut, misalnya Notaris.

Profesi hukum terutama yang bergerak dibidang jasa dan pelayanan masyarakat, salah satunya adalah Notaris. Notaris sebagai penyedia jasa terdapat di Pasal 1 angka 1 Undang-undang Nomor 2 Tahun 2014 tentang Perubahan Atas Undang-undang Nomor 30 Tahun 2004 Tentang Jabatan Notaris yang disahkan di Jakarta, (yang selanjutnya disebut sebagai UUJN) mengatur bahwa notaris memiliki beberapa kewenangan yang diatur oleh UUJN dan salah satunya adalah membuat akta otentik. Akta otentik merupakan alat bukti yang berupa surat, dibuat berdasarkan ketentuan yang diatur Undang-undang dan dibuat oleh pegawai umum yang berkepentingan menurut Undang-undang. ${ }^{1}$ UUJN memberikan pembaharuan dan memberikan suatu pengaturan khususnya mengenai jabatan notaris, sehingga UUJN

1 Salim HAL.S, (2015), Teknik Pembuatan Akta Satu (Konsep Teoritis, Kewenangan Notaris, Bentuk dan Minuta Akta), Jakarta: PT. Raja Grafindo Persada, h. 201. 
merupakan unifikasi hukum terkait dalam jabatan notaris. UUJN sebagai norma hukum yang dibuat untuk mengatur notaris berisi tentang hal-hal yang diwajibkan, dilarang, kewenangan Notaris, dan beberapa hal yang berkaitan dengan Notaris dalam menjalankan jabatannya seperti wilayah kerja, cuti, hingga organisasi semuanya diatur dalam UUJN.

Notaris sebagai pejabat umum memberikan jasanya kepada masyarakat karena masyarakat dan Notaris memiliki hubungan yang saling ketergantungan dimana masyarakat yang ingin membuat perjanjian membutuhkan alat bukti agar terciptanya kepastian hukum, kemudian masyarakat tersebut membutuhkan Notaris untuk membuat akta otentik berdasarkan kewenangannya sebagai pejabat negara, tanpa adanya permintaan sehingga tidak akan ada gunanya Notaris ${ }^{2}$. Sehingga Notaris memiliki salah satu tugas dan kewajiban utama yakni membuat akta. Akta merupakan salah satu alat bukti yang sengaja dibuat secara tertulis. ${ }^{3}$ Notaris menjadi media antara masyarakat dengan alat bukti agar terciptanya kepastian hukum. Tujuan hukum salah satunya adalah mewujudkan suatu kepastian hukum selain mewujudkan suatu keadilan dan kemanfaatan. Hukum berfungsi untuk memberikan keadilan, menjaga hak masing-masing individu, serta memelihara kepentingan umum dalam masyarakat. Tujuantujuan hukum tersebut haruslah berjalan dengan beriringan tanpa pertentangan, karena manusia merupakan makhluk sosial yang hidup dalam masyarakat dan dalam menjalankan kehidupannya berdasarkan pada hukum yang diatur oleh pemerintah sebagai suatu konsep dasar. ${ }^{4}$ Kepastian hukum yang diberikan Notaris termasuk di dalam pelaksanaan tugas dan jabatannya yang tidak terlepas dari aturan-aturan khusus Notaris agar dalam melaksanakan tugas dan jabatannya tersebut tidak melanggar ketentuan-ketentuan dalam aturan perundangundangan seperti UUJN.

Dasar hukum mengenai Notaris tidak hanya terdapat dalam aturan perundang-undangan saja seperti UUJN, namun juga terdapat dalam Kode Etik. Notaris memiliki tanggungjawab kepada masyarakat yang menggunakan jasanya, wajib mengikuti aturan dalam UUJN maupun Kode Etik Notaris selaku kaidah moral dan turut serta dalam organisasi jabatan (Ikatan Notaris Indonesia yang selanjutnya disebut sebagai INI) maupun kepada Negara ${ }^{5}$, karena profesi hukum seperti Notaris memerlukan adanya payung perlindungan, dengan adanya Kode Etik Notaris maka Notaris diharapkan memiliki kaidah moral diluar dari peraturan perundangundangan demi terlaksananya etika profesi yang baik di masyarakat. Sarana kontrol sosial ditujukan agar masyarakat diharapkan tetap memiliki kepercayaan kepada notaris karena dengan terjaminnya kepentingan tersebut maka kepercayaan masyarakat kepada notaris akan semakin kuat. ${ }^{6}$

INI membentuk Kode Etik Notaris sebagai kaidah moral bagi notaris. Etika profesi yang menjadi ranah INI berkaitan dengan aspek moralitas notaris sebagai pemegang sekaligus pengemban jabatan. ${ }^{7}$ Berdasarkan kongres yang diatur dalam aturan perundang-undangan dan wajib ditaati bagi seluruh anggota organisasi INI dan maupun yang sedang melaksanakan

\footnotetext{
${ }^{2}$ Witasari, A. (2018). Mpd Bukan Advokat Para Notaris Berdasarkan Undang-undang No. 30

Tahun 2004 Tentang Jabatan Notaris. Jurnal Hukum, 28(2), 882-899, h. 891.

3 Pieter I Made Puryatma, (2016), Teknik Dasar Pembuatan Akta Notaris, Denpasar, hal. 1.

4 Dwisvimiar, I. (2011). Keadilan dalam Perspektif Filsafat Ilmu Hukum. Jurnal Dinamika Hukum, 11(3), h. 526.

5 Endang, P. (2011). Penegakan Hukum Jabatan Notaris Dalam Pembuatan perjanjian Berdasarkan Pancasila dalam Rangka Kepastian Hukum, Jurnal Hukum Fh Yarsi, 2(3), 323-334, h. 330.

6 Prayojana, D. A., Murni, R. R., \& Dharmawan, N. K. S. (2018). Pelaksanaan Penyelesaian Pelanggaran Kode Etik Notaris Tentang Pemasangan Papan Nama Notaris Di Kota Denpasar. Acta Comitas, 213-218, h. 214.

7 Bachrudin, B. (2015). Jabatan Notaris Di Indonesia Dalam Jerat Liberalisasi. Jurnal Pembaharuan Hukum, 2(2), 185-196, h. 191.
} 
jabatan notaris sebagaimana yang diatur dalam kode etik notaris. Organisasi yang satu-satunya diakui adalah Ikatan Notaris Indonesia (selanjutnya disebut sebagai INI). INI terdapat di Pasal 82 ayat (2) UUJN bahwa wadah organisasi yang dihimpun oleh notaris adalah INI. INI didirikan pada tanggal 1 Juli 1908 dengan berbentuk badan hukum. Organisasi INI berfungsi untuk mengurangi terjadinya pelanggaran dalam pelaksanaan tugas dan jabatan Notaris, maka diperlukan adanya organisasi Notaris sebagai wadah Notaris untuk mengeluarkan aspirasinya terkait jabatan Notaris. Adanya organisasi Notaris, maka pelanggaran-pelanggaran dapat diminimalisir karena Notaris dapat saling bertukar informasi mengenai perbuatan-perbuatan yang boleh maupun tidak boleh diperbuat selama melaksanakan kewenangannya.

UUJN menyatakan bahwa satu-satunya wadah organisasi notaris resmi di Indonesia adalah INI, didukung Putusan Mahkamah Konstitusi Nomor: 009-014/PUU-III/2005 diputuskan bahwa INI merupakan organisasi tunggal notaris di Indonesia yang diakui oleh Undangundang. Seseorang yang akan diangkat menjadi Notaris wajib melaksanakan ujian pengangkatan Anggota Luar Biasa (selanjutnya disebut sebagai ALB) sebagai anggota dari organisasi INI, setelah menjadi anggota luar biasa barulah calon notaris dapat diangkat sebagai notaris. Sehingga dapat disimpulkan bahwa agar seseorang dapat menjabat seorang Notaris wajib untuk menjadi anggota organisasi Notaris, sebagaimana organisasi yang dimaksud adalah INI.

Norma hukum di Pasal 16 ayat (1) UUJN, mengatur bahwa seorang notaris wajib untuk bersikap netral, amanah, seksama, jujur, dapat menjaga kepentingan para klien dan mandiri. Terdapat kekaburan norma dalam kata "amanah" yakni amanah bagaimana yang dimaksud di dalam UUJN terutama apabila dikaitkan dengan kewajiban keanggotaan notaris dalam organisasi INI. Seluruh norma yang terdapat dalam Pasal 16 merupakan norma perintah yang artinya norma tersebut mewajibkan, tidak boleh disimpangi, dan tanpa adanya pengecualian. Norma yang bersifat mewajibkan tersebut harus dilaksanakan apapun keadaannya oleh setiap orang yang terkait dalam norma tersebut, karena sifatnya yang mewajibkan maka norma tersebut memiliki konsekuensi bagi yang tidak menjalankannya. Namun dalam hal ini Pasal 16 UUJN sebagai dasar bagi kewajiban notaris memiliki kekaburan norma dalam hal kriteria tindakan amanah apabila dikaitkan dengan kewajiban keanggotaan notaris dalam INI.

Berdasarkan kekaburan norma yang terdapat di Pasal 16 ayat (1) huruf a UUJN, maka penulis tertarik untuk menyusun jurnal yang berjudul: "KEANGGOTAAN NOTARIS DALAM ORGANISASI IKATAN NOTARIS INDONESIA: MANDATORY VS VOLUNTARY". Berdasaarkan atas latar belakang masalah, perumusan permasalahan dalam jurnal ini mengenai: Bagaimana pengaturan kewajiban keanggotaan Notaris dalam INI menurut UUJN? Dan Bagaimana sanksi apabila seorang Notaris tidak ikut menjadi anggota dalam organisasi INI?

Penulisan ini memiliki tujuan untuk mengelaborasi dan memahami pengaturan kewajiban keanggotaan Notaris dalam INI menurut UUJN; dan untuk mengkaji dan menganalisis secara normatif bagaimana sanksi apabila seorang Notaris tidak ikut menjadi anggota dalam INI.

Kajian teoritis terkait penelitian diharapkan agar dapat berguna terutama sebagai rujukan untuk referensi khususnya ilmu kenotariatan dan memberikan sumbangan pemikiran terkait Keanggotaan Notaris dalam Organisasi Ikatan Notaris Indonesia: Mandatory vs Voluntary. Manfaat penelitian ini khususnya ditujukan secara praktis Notaris, Dosen dan Mahasiswa, masyarakat, serta penulis sendiri sebagai berikut: bagi Notaris penelitian ini dapat dijadikan referensi dalam hal Keanggotaan Notaris dalam Organisasi Ikatan Notaris Indonesia: Mandatory vs Voluntary; bagi Dosen dan Mahasiswa penelitian ini dapat dijadikan sebagai refrensi dan penunjang dalam proses belajar dan mengajar dalam hal Keanggotaan Notaris dalam Organisasi Ikatan Notaris Indonesia: Mandatory vs Voluntary; penelitian ini diharapkan bermanfaat untuk masyarakat ketika mengadapi permasalahan dalam hal Keanggotaan Notaris 
dalam Organisasi Ikatan Notaris Indonesia: Mandatory vs Voluntary; bagi penulis, hasil penelitian ini agar dapat menjadi penambah wawasan khususnya dalam hal Keanggotaan Notaris dalam Organisasi Ikatan Notaris Indonesia: Mandatory vs Voluntary dan sebagai syarat dalam menyelesaikan studi akhir di Magister Kenotariatan Universitas Udayana.

\section{Metode Penelitian}

Penelitian ini mempergunakan penelitian hukum normative. Penelitian ini didasarkan atas permasalahan kekaburan norma yakni norma UUJN, Pasal 16 ayat (1) huruf a mengenai kewajiban bertindak amanah. Pasal tersebut mewajibkan seorang Notaris untuk bertindak amanah, namun Pasal tersebut memiliki kekaburan norma yakni mengenai kriteria amanah apabila dikaitkan dengan kewajiban keanggotaan notaris dalam organisasi INI.

Penelitian ini mempergunakan pendekatan perundang-undangan serta pendekatan konsep. Penelitian ini mempergunakan: Sumber bahan hukum primer merupakan hasil penelitian yang berupa jurnal, karya ilmiah yang berasal dari beragam karya ilmiah hukum. Sumber bahan hukum sekunder merupakan aturan tertulis yang telah ditetapkan oleh Negara yang berupa Undang-undang, peraturan-peraturan eksekutif, hingga keputusan. Bahan hukum sekunder yang dimaksud, yakni peraturan perundang-undangan yang terkait penelitian, seperti: Undang-undang Dasar Negara Kesatuan Republik Indonesia Tahun 1945, Undang-undang Nomor 2 Tahun 2014 tentang Perubahan Atas Undang-undang Nomor 30 Tahun 2004 Tentang Jabatan Notaris, Putusan Mahkamah Konstitusi Nomor: 009-014/PUU-III/2005, Kode Etik Notaris, Anggaran Dasar Ikatan Notaris Indonesia, dan Anggaran Rumah Tangga Ikatan Notaris Indonesia. Bahan hukum tertier merupakan penjelasan dari bahan hukum sebelumnya berupa majalah, Koran, maupun artikel dalam bentuk tertulis hingga media elektronik. Penelitian ini menggunakan metode tunggal yakni studi kepustakaan yakni dengan meneliti peraturan perundang-undangan terkait. Penerapan teknik tersebut yakni menggunakan metode bola salju (snow ball) yakni dengan mencari buku melalui referensi satu buku ke buku lainnya. Penelitian ini mempergunakan teknik deskripsi, interpretatif, evaluatif, sistematif dan argumentatif.

\section{Hasil Dan Pembahasan}

\subsection{Kewajiban Keanggotaan Notaris sebagai anggota Ikatan Notaris Indonesia}

Notaris merupakan salah satu jabatan sebagai perpanjangan tangan pemerintah dibidang jasa guna melayani kepentingan masyarakat. Jabatan merupakan pekerjaan yang dipercayakan untuk melayani kepentingan Negara maupun kepentingan masyarakat umum. Notaris dalam hubungannya dengan pemerintah adalah perpanjangan tangan negara, sebagai jabatan yang dipercayakan untuk mengerjakan beberapa urusan terkait kenegaraan yang secara eksklusif dalam ranah hukum perdata. ${ }^{8}$ Kepentingan hukum masyarakat yang dilindungi oleh notaris diharapkan dapat menjadi jawaban dari kebutuhan masyarakat. ${ }^{9}$

Pasal 16 UUJN mengatur mengenai kewajiban notaris dalam pelaksanaan kewenangannya sehari-hari, salah satunya adalah notaris wajib bersikap netral, amanah, seksama, jujur, dapat menjaga kepentingan para klien dan mandiri. Kata "amanah" memiliki kekaburan norma, amanah bagaimana yang wajib untuk dilaksanakan oleh notaris? Dengan mempergunakan

\footnotetext{
8 Nyoman, I. W. B. S. L., Martana, A., Tjukup, I. K. M. I. K., Dananjaya, N. S., \& Putra, I. P. R. A. Akta Notaris (Akta Otentik) Sebagai Alat Bukti Dalam Peristiwa Hukum Perdata. Acta Comitas. 1(2), 180-188, h. 182.

9 Mahmoud, A. R. (2014). Implikasi Hukum Bagi Notaris yang Tidak Melekatkan Sidik Jari Penghadap Pada Minuta Akta. Kumpulan Jurnal Mahasiswa Fakultas Hukum, 1(1), h. 3.
} 
teori penafsiran yang dikemukakan oleh J.A. Pontier, bahwa dengan penafsiran maka hukum dapat mengatur masyarakat. ${ }^{10}$ Metode-metode penafsiran antara lain: penafsiran gramatikal, penafsiran historis, penafsiran sistematis, penafsiran teologis, penafsiran komparatif, penafsiran futuristis, dan penafsiran otentik. Penelitian ini menggunakan penafsiran gramatikal untuk menyelesaikan permasalahan kekaburan norma tersebut. penafsiran gramatikal yakni penafsiran dengan mempergunakan tatabahasa atau kebiasaan sebagai pedoman pada norma yang kabur di Pasal 16 ayat (1) huruf a UUJN, maka kekaburan norma tersebut dapat di tafsirkan.

Menurut Kamus Besar Bahasa Indonesia (selanjutnya disebut sebagai KBBI), kata "amanah" berarti bahwa (1) sesuatu yang dipercayakan (dititipkan) kepada orang lain; (2) keamanan; ketentraman; dan (3) dapat dipercaya. ${ }^{11}$ Sehingga menurut KBBI, amanah merupakan sesuatu yang dapat dipercayakan kepada orang lain. Amanah dan keterpercayaan menjadi disposisi terhadap kepercayaan, seperti jujur, kompetensi, integritas, dan kebajikan.12 Artinya amanah merupakan kecendrungan terhadap kepercayaan, seperti jujur, kompetensi, integritas, dan kebajikan. Menurut KBBI, integritas merupakan keadaan, sifat, atau mutu yang berpotensi untuk memancarkan sifat jujur dan wibawa. ${ }^{13}$ Sedangkan kesatuan menurut KBBI merupakan sifat tunggal; kesatuan ciri khas pada orang di masyarakat. ${ }^{14}$ Apabila disimpulkan pengertian "amanah" diatas, amanah merupakan sesuatu yang dipercayakan kepada orang lain atau sesuatu yang memiliki kecendrungan terhadap kesatuan orang yang memiliki ciri tertentu.

Kata "amanah" dalam UUJN merujuk kepada kesatuan orang yang memiliki ciri tertentu, dalam kaitannya dengan notaris, kesatuan yang dimaksud merupakan perkumpulan notaris atau organisasi notaris yang dikenal sebagai INI. INI merupakan lembaga yang berwenang mengawasi agar dalam pelaksanaannya tugas dan jabatan Notaris tidak melenceng dari aturan udang-undang maupun kode etik. INI merupakan organisasi tunggal notaris yang diakui di Indonesia, sebagaimana yang diatur dalam UUJN bahwa hanya satu organisasi notaris yakni INI. Sebagai organisasi tunggal yang diakui, maka pada dasarnya tidak boleh ada organisasi resmi diluar INI. Pasal 82 ayat (1) UUJN tersebut mewajibkan bahwa hanya terdapat satu organisasi notaris, yakni INI. Karena sifat dari Pasal 82 ayat (1) yang terdapat dalam UUJN tersebut Notaris mengakui INI sebagai organisasi tunggal. INI sebagai lembaga Notaris berwenang untuk menentukan mengenai anggota dalam organisasi. Sebagai satu-satunya organisasi Notaris yang diakui oleh Undang-undang, INI memiliki kewenangan untuk mengatur mengenai anggota dalam organisasi. Kewenangan itu didapat dalam UUJN karena INI merupakan satu-satunya wadah Notaris dan setiap Notaris merupakan anggota dari INI. Kewenangan yang dimiliki INI tersebut termasuk dalam kewenangan atribusi, karena kewenangan atribusi merupakan kewenangan dari Undang-undang kepada organ pemerintahan lain yang terdapat dalam peraturan perundang-udangan. UUJN memberikan kewenangan atribusi kepada INI. Sebagaimana diketahui Notaris dalam menjalankan tugasnya sudah sepantasnya berpatokan pada kode etik notaris, lebih lanjut notaris juga diawasi oleh Dewan Kehormatan Notaris agar tidak mengabaikan martabat profesinya yang luhur sebagai pejabat negara. ${ }^{15}$

10 J.A. Pontier, (2008), Penemuan Hukum, diterjemahkan oleh B. Arief Sidharta, Bandung: Jendela Mas Pustaka, hal.94.

${ }^{11} \mathrm{Http}: / /$ kbbi.co.id/arti-kata-amanah, diakses pada 23 April 2018.

12 Husni, D. Pengukuran Konsep Amanah dalam Pendekatan Kualitatif dan Kuantitatif. Jurnal Psikologi, 43(3), 194-206, h. 203.

${ }^{13} \mathrm{Http}: / /$ kbbi.co.id/arti-kata-integritas, diakses pada 23 April 2018.

${ }^{14} \mathrm{Http}$ // kbbi.co.id/arti-kata-kesatuan, diakses pada 23 April 2018.

${ }^{15}$ Handayani, T. U., \& Mashdurohatun, A. (2018). Urgensi Dewan Kehormatan Notaris Dalam

Penegakan Kode Etik Notaris Di Kabupaten Pati. Jurnal Akta, 5(1), 51 
Selain UUJN yang mengatur mengenai organisasi INI, terdapat pula aturan mengenai organisasi yang diatur dalam Anggaran Rumah Tangga INI (yang selanjutnya disebut sebagai ART INI). Pasal 3 ayat (1) mengatur bahwa setiap notaris Indonesia merupakan anggota biasa yang wajib terdaftar dalam perkumpulan secara administrasi, artinya seorang Notaris wajib untuk mendaftarkan diri sebagai anggota INI. Syarat-syarat administratif terdapat dalam Pasal 3 ayat (2), yakni: telah melunasi iuran wajib anggota, telah terdaftar sebagai anggota luar biasa, telah mengambil sumpah jabatan Notaris, dan memiliki sk pengangkatan Notaris.

ART INI selain mengatur mengenai syarat sebagai anggota organisasi INI, juga mewajibkan anggota INI untuk wajib berpartisipasi secara aktif dalam organisasi INI sebagaimana yang terdapat dalam Pasal 7 ayat (2) ART INI.

Kewajiban keanggotaan INI pada Notaris tidak hanya terdapat dalam UUJN maupun ART INI saja, namun di dalam aturan kode etik diatur pula kewajiban keanggotaan. Kewajiban keanggotaan bagi Notaris tersebut diatur dalam kewajiban Notaris Pasal 3 angka 10, bahwa Notaris wajib untuk hadir dan aktif dan turut berpartisipasi di kegiatan yang diselenggarakan oleh organisasi INI. Kode Etik Notaris mewajibkan Notaris untuk aktif dalam kegiatan yang diselenggarakan oleh organisasi INI, sehingga Notaris tersebut wajib untuk menjadi bagian sebagai anggota dalam organisasi INI.

Peraturan perundang-undangan terkait dengan Notaris mewajibkan Notaris untuk menjadi anggota dari organisasi INI. Sebelumnya, Mahkamah Konstitusi (selanjutnya disebut sebagai MK) telah mempersilahkan bagi notaris yang ingin mengajukan keberatan ataupun gugatan dalam hal INI sebagai organisasi tunggal karena menurut MK ketentuan ini berada pelaksanaan peraturan bukan dalam tatanan normatif. ${ }^{16}$ Putusan Mahkamah Konstitusi Nomor: 009-014/PUU-III/ 2005 (selanjutnya disebut sebagai Putusan MK 09/2005) mengenai uji materiil antara Undang-undang Dasar Negara Kesatuan Republik Indonesia Tahun 1945 (selanjutnya disebut sebagai UUD'45) vs UUJN. Pasal yang diajukan untuk uji materiil dalam UUJN adalah Pasal 82 ayat (1) mengenai organisasi INI sebagai satu himpunan wadah organisasi Notaris yang dianggap bertentangan dengan Pasal 28 E ayat (3) mengenai hak setiap individu dalam hal berpendapat, berkumpul, dan berserikat yang bebas dan Pasal 28 G ayat (1) mengenai perlindungan yang berhak diperoleh setiap individu terkait hak asasi. Pemohon perkara tersebut adalah Himpunan Notaris Indonesia (selanjutnya disebut sebagai HNI) dan Persatuan Notaris Reformasi Indonesia (selanjutnya disebut sebagai PERNORI) yang mengajukan uji materil terhadap UUJN kepada UUD'45, PERNORI dan HNI menganggap bahwa Pasal 82 ayat (1) UUJN tersebut bertentangan dengan UUD'45 yakni melanggar kebebasan seseorang untuk berorganisasi. Putusan MK 09/2005 tersebut menolak permohonan PERNORI dan HNI, karena beberapa hal, seperti:

a. Menurut Hakim MK Pasal 82 ayat (1) UUJN tidak melanggar ketentuan dalam UUD'45, karena Notaris sama halnya seperti individu atau masyarakat pada umumnya yakni bebas untuk berpendapat, berserikat dan berkumpul, namun untuk melaksanakan hal tersebut haruslah berhimpun dalam satu organisasi Notaris saja agar mengurangi penyalahgunaan yang terjadi dalam rangka menjalankan tugas dan jabatannya sebagai Notaris;

b. Hakim MK menganggap hanya diperlukan satu organisasi sebagai wadah untuk mencapai fungsi membina, mengembangkan, dan mengawasi Notaris, agar pemerintah dapat dengan mudah untuk mengawasi notaris sebagai pejabat Negara; dan

c. Hampir semua Negara menganut hanya satu organisasi Notaris;

Atas dasar tersebut diatas maka Hakim MK memutuskan untuk menolak permohonan PERNORI dan HNI.

16 Ghansham Anand, (2018), Karakteristik Jabatan Notaris di Indonesia; Edisi Pertama, Jakarta: Prenadamedia Group, h. 128. 
Tidak hanya peraturan dalam UUJN, kode etik, Putusan MK 09/2005 saja yang mewajibkan notaris untuk menjadi anggota organisasi yang satu-satunya diakui, calon notaris yang akan menjalani pengangkatan menjadi notaris wajib untuk menjadi anggota organisasi notaris sebagaimana yang terdapat dalam Pasal 82 ayat (5) UUJN bahwa pembinaan, pengawasan, peraturan organisasi, dan penetapan sebagai landasan filosofis diatur dalam Peraturan Menteri Hukum dan Hak Asasi Manusia Republik Indonesia Nomor 25 Tahun 2017 tentang Ujian Pengangkatan Notaris mengatur bahwa notaris harus dinyatakan lulus oleh organisasi dalam ujian kode etik agar dapat mengajukan pendaftaran.

Peraturan Perkumpulan Ikatan Notaris Indonesia Nomor: 06/PERKUM/INI/2017 tentang Magang khususnya Pasal 6 ayat (1) angka 3 mengatur bahwa calon notaris merupakan Anggota Luar Biasa (selanjutnya disebut sebagai ALB) INI. Kewajiban keanggotaan Notaris dalam INI merupakan suatu kewajiban bagi Notaris untuk menjadi bagian sebagai anggota dalam organisasi INI, dan keberadaan organisasi INI telah diakui sebagai satu-satunya organisasi Notaris yang sah.

Melihat dari peraturan-peraturan yang mewajibkan notaris sebagai anggota INI dan INI sebagai satu-satunya organisasi yang sah dan diakui di Indonesia maka Pasal 16 ayat (1) huruf a yang memiliki kekaburan norma dapat ditafsirkan bahwa "amanah" merupakan kewajiban notaris untuk ikut sebagai anggota organisasi sebagaimana organisasi yang dimaksud adalah INI, sehingga menjadi anggota dalam INI merupakan kewajiban notaris.

\subsection{Konsekuensi bagi notaris yang Tidak Menjadi Anggota Ikatan Notaris Indonesia}

Norma adalah aturan-aturan yang bersifat wajib atau mengatur dan apabila tidak dilaksanakan dapat dikenai sanksi. Sifat hukum terbagi atas 2 jenis, yakni norma yang bersifat mengatur dan norma yang bersifat mewajibkan. Kaidah hukum mengatur mengenai perilaku masyarakat yang damai, teratur, aman, dan tertib dalam masyarakat. Sifat mewajibkan dalam kaidah hukum merupakan hukuman yang diberikan kepada orang yang melanggar dan diberikan oleh penegak hukum. ${ }^{17}$ Norma yang bersifat mengatur adalah norma yang bersifat sebagai himbauan, sifat himbauan tersebut tidak wajib untuk dilaksanakan. Misalnya Pasal 20 ayat (1) UUJN mengenai notaris boleh membentuk persekutuan perdata namun harus memperhatikan ketidakberpihakan maupun kemandirian dalam pelaksanaannya. Pasal 20 ayat (1) UUJN tersebut tidak mewajibkan notaris untuk membentuk suatu persekutuan perdata, Notaris dapat memilih untuk membentuk persekutuan perdata atau tidak.

Norma yang bersifat mewajibkan adalah norma yang wajib ditaati dan apabila tidak ditaati akan dikenakan sanksi, contoh dari hukum yang bersifat mewajibkan adalah norma-norma yang terdapat dalam Pasal 16 UUJN mengenai kewajiban Notaris. Norma tersebut dibentuk oleh pembentuk Undang-undang yang ditujukan bagi pihak tertentu yang diatur dalam Undang-undang terkait agar dapat dijalankan, norma tersebut tidak memberikan pengecualian sehingga tidak terdapat celah bagi seseorang untuk melakukan kebalikan dari norma tersebut dalam keadaan apapun, dimanapun, dan kapanpun. Apabila terdapat penyimpangan, maka akan timbul konsekuensi atau sanksi. Sanksi diberikan kepada orang yang terbukti melanggar ketentuan hukum yang dibebankan secara sengaja berupa suatu derita. Namun sanksi tidak hanya dapat berupa derita saja, tetapi dapat berupa hadiah. Sanksi adalah penerapan dari akibat hukum yang dapat berbentuk sebagai ancaman atau sebagai sebuah pembelajaran. Pada umumnya terdapat 3 (tiga) jenis sanksi yang dapat dikenai oleh notaris, yakni sanksi perdata, sanksi pidana, dan sanksi administratif. Notaris yang terbukti melanggar dapat dijatuhi sanksi

17 Najwan, J. (2009). Konflik Antar Budaya dan Antar Etnis di Indonesia Serta Alternatif Penyelesaiannya. Jurnal Hukum IUS QUIA IUSTUM, 16, 195-208, h. 205. 
kode etik maupun administrasi/perdata. ${ }^{18}$ Sanksi perdata merupakan sanksi yang dikenai apabila melanggar Kitab Undang-undang Hukum Perdata (KUHPer). Sanksi bagi yang melakukan perlawanan hukum menurut KUHPer terdapat dalam Pasal 1365 bahwa ganti rugi wajib diberikan apabila ada orang lain yang dirugikan dalam hal pelanggaran hukum. Sanksi pidana diterapkan apabila terjadi pelanggaran dalam ketentuan perbuatan melanggar hukum menurut Kitab Undang-undang Hukum Pidana (KUHP). Suatu perbuatan dikualifikasi sebagai perbuatan melawan hukum apabila perbuatan tersebut mencocoki rumusan Undang-undang pidana. ${ }^{19}$ Sedangkan sanksi administratif dapat dikenakan apabila orang yang melakukan pelanggaran terkait dengan jabatan yang diembannya.

Pasal 16 ayat (1) huruf a UUJN mewajibkan notaris untuk bersikap netral, jujur, amanah, seksama, dapat menjaga kepentingan para klien dan mandiri. Telah dijelaskan sebelumnya bahwa terjadi kekaburan norma pada Pasal tersebut yakni kata "amanah" yang kemudian disimpulkan bahwa amanah merupakan sesuatu yang dipercayakan kepada kesatuan orangorang dengan ciri tertentu yang dalam hal ini adalah INI. Sehingga notaris diwajibkan ikut serta sebagai anggota organisasi INI.

Norma Pasal 16 ayat (1) merupakan norma hukum bersifat mewajibkan yang apabila tidak ditaati maka akan dikenai sanksi. Terkait hal tersebut, maka ditafsirkan bahwa diwajibkan untuk melaksanakan amanah untuk ikut serta sebagai anggota dalam organisasi INI maka apabila ada notaris yang tidak turut serta sebagai bagian dalam organisasi INI maka notaris tersebut melanggar ketentuan dalam pasal tersebut. Konsekuensi apabila notaris melanggar ketentuan dalam pasal tersebut dapat dijatuhkan sanksi yakni: peringatan tertulis, pemberhentian sementara, pemberhentian dengan hormat dan pemberhentian dengan tidak hormat.

Notaris apabila tidak mengikuti kewajiban-kewajiban dalam UUJN khususnya kewajiban sebagai anggota organisasi INI dapat dikenai sanksi administratif karena Pasal 16 UUJN termasuk dalam norma yang bersifat mewajibkan, sehingga tidak ada pilihan lain bagi Notaris untuk tidak mengikuti aturan tersebut yakni sebagai anggota dari organisasi INI. Penerapan sanksi administratif ini dimulai dari diberikan teguran tertulis sebagai peringatan dari Majelis Pengawas apabila teguran tersebut masih tidak digubris oleh notaris maka kemudian diberikan pemberhentian sementara, namun apabila pemberhentian sementara tersebut masih tidak diindahkan oleh notaris maka sanksi berikutnya diberikan secara bertahap. Penerapan sanksi tersebut tergantung atas berat atau tidaknya pelanggaran yang diperbuat, sehingga penerapannya bersifat berjenjang. ${ }^{20}$

Pelanggaran mengenai kewajiban keanggotaan notaris dalam INI tidak dapat dikenai sanksi perdata, karena sanksi perdata dalam Pasal 1365 KUHPer bahwa setiap pelanggaran yang menyebabkan kerugian maka harus memberikan ganti rugi, artinya seseorang dapat dikenai sanksi perdata apabila perbuatannya tersebut telah melanggar ketentuan perdata dan juga merugikan orang lain. Dalam hal ini, ketidakikutsertaan seorang notaris sebagai bagian dari anggota organisasi INI tidak merugikan orang lain, melainkan merugikan dirinya sendiri, sehingga tidak dapat dikenai sanksi perdata. Sanksi pidana juga dapat diberikan kepada notaris

18 Cahyanti, N., \& Wahyuningsih, S. E. (2018). Sanksi Terhadap Notaris Yang Melakukan Tindak Pidana Menurut Peraturan Perundang-Undangan Di Indonesia. Jurnal Akta, 5(1), 288294, h. 289.

${ }_{19}$ Prastowo, R. B. (2006). Delik Formil/Materiil, Sifat Melawan Hukum Formil/Materiil Dan Pertanggungjawaban Pidana Dalam Tindak Pidana Korupsi. Jurnal Hukum Pro Justitia, 24(3), 212-226, h. 221.

20 Setiabudhi, I. K. R., \& Swardhana, G. M. (2017). Sanksi Hukum Terhadap Notaris Yang Melanggar Kewajiban Dan Larangan Undang-Undang Jabatan Notaris. Acta Comitas, 110-121, h. $115-116$. 
dalam prakteknya selain pemberian sanksi perdata maupun administratif. ${ }^{21}$ Namun terkait dengan ketidakikutsertaan seorang notaris sebagai anggota organisasi INI dianggap kurang tepat apabila dikenai sanksi pidana, karena pelanggaran tersebut tidak melanggar ketentuan sebagaimana yang terdapat dalam KUHP. Sehingga, seorang notaris apabila tidak ikut serta sebagai anggota dalam organisasi INI dapat dikenai sanksi berupa sanksi administratif. Sanksi administratif tersebut dikenakan kepada notaris dalam hal jabatan notaris, bukan sebagai kesalahan individu. Selain sanksi perdata, pidana dan administratif, notaris tersebut juga dapat dikenai sanksi sosial. Sanksi sosial dapat berupa dikucilkan di masyarakat maupun antar sesama notaris karena dianggap tidak mau bersosialisasi dengan sesama notaris.

\section{Kesimpulan}

Notaris wajib menjadi anggota dalam organisasi INI, sebagaimana yang terdapat dalam UUJN bahwa notaris wajib untuk bertindak amanah. Tindakan amanah ditafsirkan sebagai sesuatu yang dipercayakan kepada kesatuan orang, yang dalam hal ini adalah INI. Pengaturan mengenai kewajiban keangggotaan notaris dalam INI terdapat dalam UUJN, Kode Etik Notaris dan Putusan MK; dan Notaris yang tidak ikut dalam keanggotaan INI mendapatkan sanksi berupa peringatan tertulis, pemberhentian sementara, pemberhentian dengan hormat, atau pemberhentian dengan tidak hormat.

Agar dalam UUJN dapat diperjelas mengenai kriteria amanah terutama terkait kewajiban keangggotaan notaris sebagai anggota organisasi INI. Kepada Ikatan Notaris Indonesia agar dapat menambahkan ketentuan mengenai konsekuensi bagi notaris yang tidak menjadi bagian dalam keanggotaan INI.

\section{Daftar Pustaka}

\section{$\underline{\text { Buku }}$}

Ghansham Anand, (2018), Karakteristik Jabatan Notaris di Indonesia; Edisi Pertama, Jakarta: Prenadamedia Group.

J.A. Pontier, (2008), Penemuan Hukum, diterjemahkan oleh B. Arief Sidharta, Bandung: Jendela Mas Pustaka.

Pieter I Made Puryatma, (2016), Teknik Dasar Pembuatan Akta Notaris, Denpasar.

Salim HAL.S, (2015), Teknik Pembuatan Akta Satu (Konsep Teoritis, Kewenangan Notaris, Bentuk dan Minuta Akta), Jakarta: PT. Raja Grafindo Persada.

\section{Jurnal}

Bachrudin, B. (2015). Jabatan Notaris Di Indonesia Dalam Jerat Liberalisasi. Jurnal Pembaharuan Hukum, 2(2), 185-196.

Cahyanti, N., \& Wahyuningsih, S. E. (2018). Sanksi Terhadap Notaris Yang Melakukan Tindak Pidana Menurut Peraturan Perundang-Undangan Di Indonesia. Jurnal Akta, 5(1), 288-294. http://jurnal.unissula.ac.id/index.php/akta/article/view/2617

${ }^{21}$ Juwita, N. (2013). Kesalahan Ketik dalam Minuta Akta Notaris yang Salinannya Telah Dikeluarkan. CALYPTRA, 2(2), 1-2, h. 15. 
Dwisvimiar, I. (2011). Keadilan dalam Perspektif Filsafat Ilmu Hukum. Jurnal Dinamika Hukum, 11(3). http://dx.doi.org/10.20884/1.jdh.2011.11.3.179

Endang, P. (2011). Penegakan Hukum Jabatan Notaris Dalam Pembuatan perjanjian Berdasarkan Pancasila dalam Rangka Kepastian Hukum, Jurnal Hukum Fh Yarsi, 2(3), 323334. http://hdl.handle.net/123456789/1422

Husni, D. Pengukuran Konsep Amanah dalam Pendekatan Kualitatif dan Kuantitatif. Jurnal Psikologi, 43(3), 194-206. https://doi.org/10.22146/jpsi.11233

Juwita, N. (2013). Kesalahan Ketik dalam Minuta Akta Notaris yang Salinannya Telah Dikeluarkan. CALYPTRA, 2(2),1-2. http://journal.ubaya.ac.id/index.php/jimus/article/view/733

Mahmoud, A. R. (2014). Implikasi Hukum Bagi Notaris yang Tidak Melekatkan Sidik Jari Penghadap Pada Minuta Akta. Kumpulan Jurnal Mahasiswa Fakultas Hukum, 1(1).

Najwan, J. (2009). Konflik Antar Budaya dan Antar Etnis di Indonesia Serta Alternatif Penyelesaiannya. Jurnal Hukum IUS QUIA IUSTUM, 16, 195-208.

Nyoman, I. W. B. S. L., Martana, A., Tjukup, I. K. M. I. K., Dananjaya, N. S., \& Putra, I. P. R. A. Akta Notaris (Akta Otentik) Sebagai Alat Bukti Dalam Peristiwa Hukum Perdata. Acta Comitas. 1(2), 180-188. https://doi.org/10.24843/AC.2016.v01.i02

Prayojana, D. A., Murni, R. R., \& Dharmawan, N. K. S. (2018). Pelaksanaan Penyelesaian Pelanggaran Kode Etik Notaris Tentang Pemasangan Papan Nama Notaris Di Kota Denpasar. Acta Comitas, 213-218.

Prastowo, R. B. (2006). Delik Formil/Materiil, Sifat Melawan Hukum Formil/Materiil Dan Pertanggungjawaban Pidana Dalam Tindak Pidana Korupsi. Jurnal Hukum Pro Justitia, 24(3), 212-226.

Witasari, A. (2018). Mpd Bukan Advokat Para Notaris Berdasarkan Undang-undang No. 30 Tahun 2004 Tentang Jabatan Notaris. Jurnal Hukum, 28(2), 882-899.

Setiabudhi, I. K. R., \& Swardhana, G. M. (2017). Sanksi Hukum Terhadap Notaris Yang Melanggar Kewajiban Dan Larangan Undang-Undang Jabatan Notaris. Acta Comitas, 110121. https://doi.org/10.24843/AC.2017.v02.i01.p10

Handayani, T. U., \& Mashdurohatun, A. (2018). Urgensi Dewan Kehormatan Notaris Dalam Penegakan Kode Etik Notaris Di Kabupaten Pati. Jurnal Akta, 5(1), 51-64.

\section{Internet}

Kamus Besar Bahasa Indonesia. Http://kbbi.co.id/arti-kata-amanah, diakses pada 23 April 2018. Http://kbbi.co.id/arti-kata-integritas, diakses pada 23 April 2018.

2018. Http://kbbi.co.id/arti-kata-kesatuan, diakses pada 23 April 